\title{
Organizational culture: prevention, treatment, and risk management of pressure injury
}

\author{
Cultura organizacional: prevenção, tratamento e gerenciamento de risco da lesão por pressão \\ Cultura organizacional: prevención, tratamiento y gestión de riesgos de la úlcera por presión
}

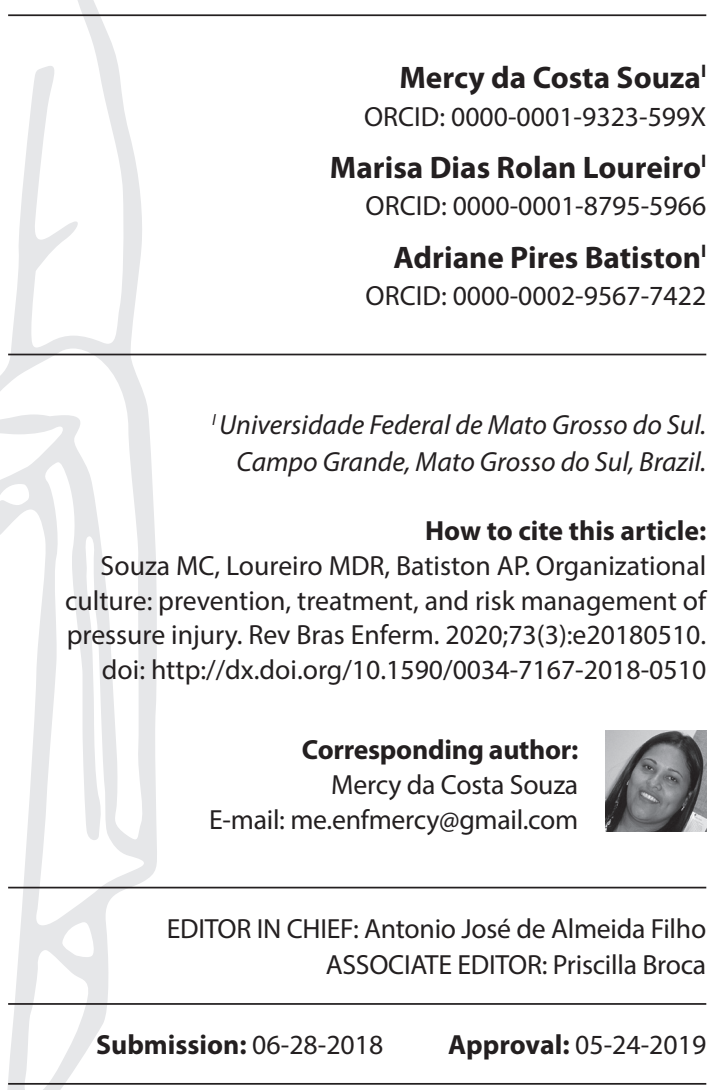

\section{ABSTRACT}

Objectives: To identify the facilitating and complicating factors for the prevention and treatment of pressure injury (PI) in the management of hospitalized patient care. Methods: This is a cross-sectional study, conducted with 197 nursing professionals in three public hospitals. Results: Among the identified factors, it is noteworthy that $59 \%$ of respondents are unaware of the PI prevention protocol, $27 \%$ do not use clinical evaluation for daily sizing of professionals, more than $52 \%$ believe that no facilitating elements exist, and $76 \%$ argue that there are complicating elements for the prevention of PI. As for the treatment, a little over $60 \%$ reported that the patient and the injury are evaluated by nurses, with $54 \%$ of the procedures being prescribed by the physician and $46 \%$ of the therapy being performed by nursing technicians. Conclusions: We conclude that the prevention and treatment of $\mathrm{PI}$ require shared management, with integrated actions among the care executors.

Descriptors: Risk Management; Patient Safety; Organizational Culture; Nursing Care; Pressure Injury.

\section{RESUMO}

Objetivos: Identificar os fatores facilitadores e dificultadores para a prevenção e tratamento da lesão por pressão (LP) na gestão da assistência ao paciente hospitalizado. Métodos: Estudo transversal, realizado com 197 profissionais de enfermagem em três hospitais públicos. Resultados: Entre os fatores identificados, destaca-se que $59 \%$ dos entrevistados desconhecem o protocolo de prevenção de LP, $27 \%$ não utilizam a avaliação clínica para dimensionamento diário dos profissionais, mais de $52 \%$ acreditam não existir elementos facilitadores e $76 \%$ afirmam existir elementos dificultadores para a prevenção de LP. Quanto ao tratamento, pouco mais de $60 \%$ referem que o paciente e a lesão são avaliados por enfermeiros, sendo que $54 \%$ dos procedimentos são prescritos pelo médico e $46 \%$ da terapêutica é executada por técnicos de enfermagem. Conclusões: Conclui-se que a prevenção e o tratamento da LP necessitam da gestão compartilhada, com ações integradas entre os executores da assistência.

Descritores: Gerenciamento de Risco; Segurança do Paciente; Cultura Organizacional; Cuidados de Enfermagem; Lesão por Pressão.

\section{RESUMEN}

Objetivos: Identificar los factores que facilitan y dificultan la prevención y el tratamiento de la úlcera por presión (UP) en la gestión de la asistencia al paciente hospitalizado. Métodos: Estudio transversal, en el cual participaron 197 profesionales de enfermería en tres hospitales públicos. Resultados: Entre los factores identificados, se destaca que el 59\% de los entrevistados desconocen el protocolo de prevención de UP, el 27\% no utilizan la evaluación clínica para el dimensionamiento diario por los profesionales, más del $52 \%$ creen que no existen elementos que la facilitan y el $76 \%$ afirman que existen elementos que dificultan su prevención. En cuanto al tratamiento, poco más del $60 \%$ señalan que el paciente y la úlcera son evaluados por enfermeros, siendo que el $54 \%$ de los procedimientos son prescriptos por el médico y el $46 \%$ de la terapia es conducida por técnicos de enfermería. Conclusiones: Se concluyó que la prevención y el tratamiento de la UP necesita una gestión compartida, con acciones integradas entre quienes ejecutan la asistencia.

Descriptores: Gestión de Riesgos; Seguridad del Paciente; Cultura Organizacional; Atención de Enfermería; Úlcera por Presión. 


\section{INTRODUCTION}

The prevention of pressure injury (PI) plays an important role in defining the quality of services offered in hospital institutions and home care. Even with scientific advances, PI remains a constant challenge for patients, relatives, multidisciplinary team, and health organizations.

For over 20 years, PI has been analyzed and classified by an universal system ${ }^{(1)}$, currently revised to better describe the etiology and development of injuries, both in the intact skin and ulcerated tissue ${ }^{(2)}$.

In Brazil, there are no accurate records of the occurrence of PI. The scarcity of statistical data becomes an obstacle to situational analysis in the national scenario ${ }^{(3)}$, hindering the management of this problem. Regional findings indicate information on the clinical epidemiology of the population most affected by $\mathrm{PI}^{(4-6)}$, which cannot be extrapolated to the Brazilian territory.

The scientific community emphasizes that, in many cases, $\mathrm{PI}$ is preventable ${ }^{(1)}$. However, its occurrence remains quite frequent, with high incidence and prevalence $\operatorname{rates}^{(7-8)}$. Thus, there is evidence of gaps in the scientific production concerning research associated with experienced practices ${ }^{(9)}$.

Other relevant findings regarding PI refer to the lack of standardization of the actions used to operationalize and standardize the conducts in a systematic way, able to contribute to the improvement of $\operatorname{care}^{(6)}$.

The theme represents a serious public health problem ${ }^{(6)}$ that worsens throughout the care and administrative sphere, that is intimately linked to the evaluation of care processes and interrelated to the patients' safe care ${ }^{(10)}$. PI prolongs patients' hospitalization and increases the risk of developing other complications, as well as reducing their independence and functionality in the accomplishment of daily living activities and compromising their quality of life and socialization ${ }^{(4,6)}$.

As a management tool, knowing the epidemiological aspects of PI becomes an important indicator of the quality of care ${ }^{(5)}$. Therefore, this issue deserves the increasing concern of management and policies, as it symbolizes an economic burden for health services ${ }^{(3-4,6)}$.

\section{OBJECTIVES}

To identify the facilitating and complicating factors for the prevention and treatment of pressure injury in the management of hospitalized patient care.

\section{METHODS}

\section{Ethical aspects}

This research was carried out in accordance with the favorable opinion of the Research with Human Beings Ethics Committee of the Federal University of Mato Grosso do Sul.

\section{Study design, location, and period}

This is a cross-sectional study carried out in three public teaching hospitals in the city of Campo Grande, state of Mato Grosso do Sul (MS), Brazil. The research scenarios were chosen by convenience and are hospitalization units for adult patients, clinical and surgical. Data collection was performed from August to October of 2013, in all work shifts.

\section{Population or sample: inclusion and exclusion criteria}

The target population of the study was the nursing team (nurses, technicians, and assistants) from three large hospitals, relevant in teaching, research, extension, and care, having, together, approximately 1,500 active beds.

The universe of individuals working in the scenarios studied was 255 professionals. The sample was calculated for each category of the aforementioned institutions, with a confidence level of $95 \%$ and a margin of error of $5 \%$. The sample composition consisted of 31 nurses, 112 technicians, and 54 nursing assistants, totaling 197 participants.

Regarding the inclusion criteria, the members of the fixed scale were part of the study, responsible for direct and indirect care of the adult patients hospitalized in the selected sectors. Those who were away due to medical leave during the data collection period were not included.

All participants signed the informed consent form.

\section{Study protocol}

A semi-structured, self-applied instrument was developed, composed by open and closed questions, divided into three different sections: the first identified the sociodemographic variables; the second addressed professional experience, educational training related to $\mathrm{PI}$, continuing education, and the knowledge and actions used in prevention, treatment, and rehabilitation; and the third characterized the actions employed in care management, such as the existence of protocols for prevention, evaluation for the guiding of the nursing team, and the identification of the professionals who evaluate the patient with $\mathrm{PI}$ and define and carry out the treatment.

For the development of the instrument, two theoretical frameworks were used: a test of recommendations for prevention and description of $\mathrm{PI}$ and the evaluation of knowledge of nursing professionals, translated and adapted to Portuguese ${ }^{(11,12)}$, and the international guide of recommendations for prevention and treatment ${ }^{(1)}$.

After the construction phase, the instrument was revised by 15 judges, experts in the area of prevention and treatment of wounds, which evaluated its objectivity, completeness, adequacy, and clarity.

After the return of the specialists' submission, each item was evaluated individually as well as the instrument as a whole, using the Likert scale to indicate its degree of agreement or disagreement and statements concerning the attitude being measured ${ }^{(13)}$. The validity index found, by the sum of agreement of the items that received only the highest score established, was 0.81 . The lowest scores and absence of response conditions were annulled.

After the analysis and adequacy of the instrument, the pilot test was performed with five nurses and seven nursing assistants/ technicians in different sectors of the research scenario, with identification of possible inconsistencies and measurement of the completion time, proceeding to the necessary adjustments to meet the proposed objective. 


\section{Analysis of the results and statistics}

The data obtained in the open questions were categorized and grouped by similarity of meaning and frequency of repetition of the contents.

The association between current occupation of the nursing professional and the variables - sex, care, training, and facilitating and complicating elements of PI prevention measures - was evaluated by Chi-square test.

The $\mathrm{Z}$ test was used to compare proportions and between two proportions in the presence of a significant association between nominal or ordinal variables with more than two possible responses. Regarding the variables of age, years in the institution, and workload per day, the Student's t test was applied and comparisons were made between nurses and nursing assistants/ technicians, considering a significance level of $5 \%$.
As for the perception of the participants concerning the existence of facilitating and complicating elements for the implementation of the preventive measures of $\mathrm{PI}$, in general, most of the interviewees $(52.8 \% ; n=104)$ believe that there are no facilitating elements. There was no statistically significant association between the current occupation of the professional and the answer about the existence of facilitating elements for the implementation of prevention measures of $\mathrm{PI}(\mathrm{p}=0.087)$. When found, the most cited was work process, in $55.9 \%$ of the answers ( $n=52)$, followed by human resources ( $45.2 \%$; $=42$ ).

Regarding the complicating elements, the percentage of nurses who affirmed their existence was significantly higher than that of nursing assistants/technicians $(p=0.044)$. Both groups did not differ among themselves when pointing out the complicating elements, such as lack of material $(70.7 \% ; n=106)$ and work overload (54.7\%; $\mathrm{n}=82$ ) (Tables 1 and 2).

\section{RESULTS}

The 197 nursing professionals participating in the study were divided into two groups: high school level workers (nursing assistants/ technicians), which corresponded to more than $80 \%$ of the individuals ( $n=166)$, and higher education level (15.7\%), totaling 31 nurses.

We observed a predominance of the female sex $(73.6 \%)$ and mean age of 36.71 years $( \pm 0.68)$, with a statistically significant association $(p=0.015)$ of age up to 30 years among nurses (51.6\%). As for the time working at the institution, there was a marked difference among the participants. High school level professionals presented a greater time of permanence in the sector when compared to the higher education level professionals $(p<0.001)$, with an average time working at the institution of $8.35 \pm 0.59$ years.

In general, there was no consensus among the participants regarding the frequency with which the management of daily care occurs, as well as the non-evaluation of the clinical condition to define the number of professionals needed for care $(p=0.176)$. On the other hand, the value differed concerning the response on the existence of a specific protocol for the prevention of $\mathrm{PI}$ in the institution $(p=0.006)$. A higher percentage of nurses $(51.6 \% ; n=16)$ reported the non-existence of the protocol when compared to nursing assistants/technicians $(24.7 \% ; n=41)$ $(p=0.005)$. On the other hand, a significantly higher percentage $(63.9 \% ; n=106)$ of high school level professionals reported that they did not know of the existence of this institutional protocol compared to nurses (35.5\%; $\mathrm{n}=11$ ) $(p=0.006)$. In addition, the number of patients cared for in a period of six and 12 hours was higher among nurses compared to nursing assistants/technicians $(p<0.001)$.

Table 1 - Current occupation and variables related to care, training, and level of knowledge about pressure injury of the interviewed professionals, Campo Grande, Mato Grosso do Sul, Brazil, $2013(\mathrm{~N}=197)$

\begin{tabular}{|c|c|c|c|}
\hline Variable & $\begin{array}{c}\text { Assistant/ } \\
\text { Technician } \\
(n=166)\end{array}$ & $\begin{array}{c}\text { Nurse } \\
(n=31)\end{array}$ & $\begin{array}{c}\text { Total } \\
(\mathrm{N}=197)\end{array}$ \\
\hline & n (\%) & n (\%) & n (\%) \\
\hline
\end{tabular}

Evaluation of the clinical condition of patients to define the quantitative number of professionals for direct care $(p=0.176)^{*}$

Always
Often
Rarely
Never
Unaware

Existence of a specific protocol for the prevention of pressure injury $(\mathrm{P}=0.006)^{*}$

Yes $(p=0.947)^{* * * *}$

Unaware $(p=0.006)^{* * *}$

Number of patients cared for in a period of 6 hours/day $(p<0.001)^{* *}$

12 hours/day $(p<0.001)^{* *}$

$\begin{array}{ccc}25(15) & 5(16.1) & 30(15.2) \\ 28(16.9) & 9(29) & 37(18.8) \\ 32(19.3) & 9(29) & 41(20.8) \\ 31(18.7) & 3(9.8) & 34(17.3) \\ 50(30.1) & 5(16.1) & 55(27.9)\end{array}$

41 (24.7)

16(51.6)

$57(28.9)$

$19(11.4)$

$106(63.9)$

4(12.9)

$11(35.5)$

$23(11.7)$

$117(59.4)$

$3.19 \pm 0.24 \quad 26.00 \pm 3.00 \quad 6.78 \pm 0.78$

$5.77 \pm 0.23 \quad 22.52 \pm 3.00 \quad 8.40 \pm 0.69$

Receiving of specific training for the prevention and treatment of pressure injury $(p=0.497)^{*}$

Yes

No

$86(51.8) \quad 14(45.2) \quad 100(50.8)$

$80(48.2) \quad 17(54.8) \quad 97(49.2)$

Offering, on the part of the institution, of training for the prevention and treatment of pressure injury $(p=0.837)^{*}$

No

Yes

No information

$\begin{array}{ccc}121(72.9) & 23(74.2) & 144(73.1) \\ 45(27.1) & 7(22.6) & 52(26.4) \\ 0(0) & 1(3.2) & 1(0.5)\end{array}$

How is the level of knowledge about the treatment and prevention of pressure injury considered $(p=0.690)^{*}$

Very good
Good
Average
Unsatisfactory

$\begin{array}{ccc}16(9.6) & 4(13) & 20(10.2) \\ 102(61.4) & 21(67.7) & 123(62.4) \\ 43(26) & 5(16.1) & 48(24.4) \\ 5(3) & 1(3.2) & 6(3)\end{array}$

Note: The results are presented in relative frequency (absolute frequency) or on average \pm standard error of the mean. ${ }^{*} P$ value in the Chi-square test. ${ }^{* *} P$ value in Student's $t$ test. ${ }^{* * *} P$ value in the $Z$ test. 
Table 2 - Distribution of the mentioned frequency of the facilitating and complicating elements for the implementation of pressure injury prevention measures among the interviewed professionals, Campo Grande, Mato Grosso do Sul, Brazil, 2013 ( $\mathrm{N}=197)$

\begin{tabular}{|c|c|c|c|}
\hline Variable & $\begin{array}{c}\text { Assistant/ } \\
\text { Technician } \\
(\mathbf{n}=166) \\
n(\%)\end{array}$ & $\begin{array}{c}\begin{array}{c}\text { Nurse } \\
(n=31)\end{array} \\
n(\%)\end{array}$ & $\begin{array}{c}\text { Total } \\
(\mathrm{N}=197) \\
\mathbf{n}(\%)\end{array}$ \\
\hline \multicolumn{4}{|c|}{$\begin{array}{l}\text { Are there facilitating elements for the implementation of } \\
\text { pressure injury prevention measures? }(p=0.087)\end{array}$} \\
\hline No & $92(55.4)$ & $12(38.7)$ & $104(52.8)$ \\
\hline Yes & $74(44.6)$ & $19(61.3)$ & $93(47.2)$ \\
\hline Facilitating elements & $\mathrm{n}=74$ & $\mathrm{n}=19$ & $\mathrm{n}=93$ \\
\hline Work process $(p=0.563)$ & $43(58.1)$ & $9(47.4)$ & $52(55.9)$ \\
\hline Human resources $(p=0.043)$ & $29(39.2)$ & $13(68.4)$ & $42(45.2)$ \\
\hline Others $(p=0.531)$ & $9(12.2)$ & $4(21.1)$ & $13(14)$ \\
\hline \multicolumn{4}{|c|}{$\begin{array}{l}\text { Are there complicating elements for the implementation of } \\
\text { pressure injury prevention measures? }(p=0.044)\end{array}$} \\
\hline No & $44(26.5)$ & $3(9.7)$ & $47(23.9)$ \\
\hline Yes & $122(73.5)$ & $28(90.3)$ & $150(76.1)$ \\
\hline Complicating elements & $\mathrm{n}=122$ & $\mathrm{n}=28$ & $\mathrm{n}=150$ \\
\hline Lack of material $(\mathrm{p}=0.892)$ & $86(70.5)$ & $20(71.4)$ & $106(70.7)$ \\
\hline Work overload $(p=0.176)$ & $63(51.6)$ & $19(67.9)$ & $82(54.7)$ \\
\hline Work process $(p=0.093)$ & $23(18.9)$ & $10(35.7)$ & $33(22)$ \\
\hline Human resources $(p=0.103)$ & $20(16.4)$ & $9(32.1)$ & $29(19.3)$ \\
\hline Others $(p=0.233)$ & $10(8.2)$ & $5(17.9)$ & $15(10)$ \\
\hline
\end{tabular}

Note: The results are presented in relative frequency (absolute frequency). *P value in chi-square test.

Table 3 - Distribution of the frequency mentioned by the interviewed professionals regarding the management of direct care, Campo Grande, Mato Grosso do Sul, Brazil, 2013 (N = 197)

\begin{tabular}{|c|c|c|c|c|c|}
\hline Variable & Nurse & Nursing team & Physician & $\begin{array}{l}\text { Nurse } \\
\text { technician }\end{array}$ & $\begin{array}{l}\text { Did not } \\
\text { answer }\end{array}$ \\
\hline $\begin{array}{l}\text { Professional who defines the } \\
\text { treatment of pressure injury }\end{array}$ & $\begin{array}{l}47.2 \% \\
n=93\end{array}$ & $\begin{array}{l}1.5 \% \\
\mathrm{n}=3\end{array}$ & $\begin{array}{l}54.3 \% \\
\mathrm{n}=61\end{array}$ & $\begin{array}{c}2 \% \\
n=4\end{array}$ & $\begin{array}{l}11.7 \% \\
\mathrm{n}=23\end{array}$ \\
\hline $\begin{array}{l}\text { Professional who carries out the } \\
\text { treatment }\end{array}$ & $\begin{array}{l}23.4 \% \\
\mathrm{n}=46\end{array}$ & $\begin{array}{l}19.3 \% \\
\mathrm{n}=38\end{array}$ & & $\begin{array}{l}46.7 \% \\
n=92\end{array}$ & $\begin{array}{l}12.2 \% \\
n=24\end{array}$ \\
\hline $\begin{array}{l}\text { Professional who evaluates the } \\
\text { individual with pressure injury }\end{array}$ & $\begin{array}{c}62.4 \% \\
n=123\end{array}$ & $\begin{array}{l}14.2 \% \\
\mathrm{n}=28\end{array}$ & $\begin{array}{l}49.7 \% \\
n=98\end{array}$ & $\begin{array}{l}31.5 \% \\
n=62\end{array}$ & $\begin{array}{c}1 \% \\
n=3\end{array}$ \\
\hline $\begin{array}{l}\text { Professional who evaluates the } \\
\text { pressure injury }\end{array}$ & $\begin{array}{c}60.9 \% \\
\mathrm{n}=120\end{array}$ & $\begin{array}{c}7.6 \% \\
n=15\end{array}$ & $\begin{array}{l}28.4 \% \\
\mathrm{n}=56\end{array}$ & $\begin{array}{l}10.7 \% \\
n=21\end{array}$ & $\begin{array}{l}13.2 \% \\
n=26\end{array}$ \\
\hline
\end{tabular}

reality and may be related to the existence of a high quantity of technical training courses ${ }^{(14)}$. The largest number of female professionals confirms the feminization of the profession ${ }^{(15)}$.

The two groups analyzed were heterogeneous, and we observed the predominance of professionals with a mean age of less than 30 years among the nurses, which diverges from the international panorama. Despite the similar age range, it differs inversely among the categories $^{(16)}$.

Similarly, we also observed a significant difference in the working time in the sector among professionals of high school and higher education levels, with eight and four years, respectively. Previous findings refer us to correlate with the lack of an organizational structure, the absence of management of career plans, working conditions, material resources, and recognition by competence ${ }^{(17-18)}$. These factors weaken the attitude and professional performance, without continuity in the care management process.

Regarding the opportunities of training for prevention and care of individuals with PI offered by the institutions to their professionals, the results revealed that educational activities on the specific theme (PI) are not offered. Since the updating of knowledge and the reflection on daily activities are not foreseen, the control of this

Concerning direct care to patients with $\mathrm{Pl}$, it was evidenced that $82.2 \%$ of the respondents $(n=162)$ request the evaluation of other professionals when faced with the injury. Physicians were the most frequently identified professionals (54.3\%) responsible for defining the treatment. In $46.7 \%$ of the cases, the therapy employed is carried out by the high school level professional, and $60 \%$ of the interviewees stated that the evaluation of the individual and of PI is carried out by the nurse (Table 3 ).

\section{DISCUSSION}

Of the total sample (197), there was a predominance of high school level professionals, which does not differ from the national aggravation becomes, thus, increasingly difficult ${ }^{(3)}$.

Continuing education reinforces the need to work with tools that seek reflections about change in the work space, especially in the health area, with a strategy of effective transformation in daily practice ${ }^{(19)}$.

Thus, one of the safe and viable measures to reduce this factor is the use of actions related to permanent/continuing education of professionals ${ }^{(3,19)}$. It is possible to notice that, in health institutions, there is great difficulty in investing in the continuous qualification of individuals.

In the evolution of science and technology, the health area presents innovative measures and achievements, including in the field of prevention and treatment of patients at risk and with PI. 
Over the years, international ${ }^{(1)}$ and national ${ }^{(20)}$ organizations have turned their gaze to some problems that can influence people's vitality and that, to some extent, impact on the care offered by professionals and services. The use of guidelines and the implementation of prevention protocols are the best strategy to strengthen the best care practices, with prevention interventions that shall consequently lead to the reduction of occurrence and complications of $\mathrm{PI}^{(3-4,21)}$.

We observed a considerable difference between the groups when questioned about the existence of a prevention protocol in the institution at which they work. Most high school level professionals were unaware of its existence, and little more than half of the nurses affirmed its inexistence, unlike the perspective that the literature presents, which emphasizes prevention as the best way, focused on the use of guidelines and protocols to minimize this event ${ }^{(10,20-21)}$.

If the prevention of PI is not easy, the treatment of an already installed injury is much more complex and expensive to the health system ${ }^{(22)}$, which requires professionals to know and apply economic fundamentals ${ }^{(3,23)}$, so that prevention is of extreme clinical value ${ }^{(10)}$ to minimize physical, psychic, and social harm to the individual, enabling a safe care practice.

The complexity of the manifestation of PI leads us to the need to develop a critical and reflective sense about the importance of a systematic clinical evaluation. Moreover, it is essential to consider the aspects related to the institutional mission, its commitment and respect to the legal attributions of ensuring the conditions for quality care, whether in planning or executing the care plan ${ }^{(4,8-9)}$.

To define strategies aimed at a management policy for PI prevention, some factors are determinant and should be prioritized in patients' clinical characterization. The use of an instrument to evaluate the risks of developing $\mathrm{PI}$ is being diffused more frequently in recent years, and the use of validated and recommended scales has been suggested, such as those by Braden ${ }^{(3,20)}$, Waterlow and Norton ${ }^{(3)}$.

The authors emphasize that the degree of dependence and the estimated time of each procedure become important indicators of management of care and human resources, and result in a safe care to the individual ${ }^{(3-4,24)}$.

As for the management tool, regarding the clinical evaluation of the patient to define the daily number of professionals, a small portion of the nurses reported that it is always applied, while one third of the nursing assistants/technicians informed that this indicator is never used.

It is necessary to reflect on the responsibility of the nurse as manager of the care offered by the other members of the nursing team and also on the technical task and the ethical duty to guide the professionals and direct the rational and efficient use of scarce and necessary resources for care $\mathrm{c}^{(3,18,24)}$.

As the inadequacy of the quantitative of professionals hinders the task of estimating the real cost of prevention and treatment of PI to the health system ${ }^{(18,25-26)}$, the number of professionals not adequately dimensioned interferes in care management, as well as in the quality of care, which leads to the imminent risk of transforming health care institutions (in this case, hospitals) into harmful environments, subject to potentially preventable adverse events.
In the implementation of PI prevention, the participants pointed out as facilitating elements priority activities for the nursing work process, such as integral care, articulated with other managerial actions. These indicate the main elements that can act directly in the achievements of precautionary actions for the occurrence of $\mathrm{PI}$, such as the trained professional and dedication to care in their ethical precepts, with systematization of care ${ }^{(3-4,26)}$.

PI has a high relevance in daily care. The main difficulties in effecting preventive measures, which were pointed out in their entirety by the nursing professionals, were the lack of materials and work overload, which are emphasized in different studies ${ }^{(3-4,18-19)}$. They reinforce the absence of training, the lack of financial support from the institutions for prevention and the adoption of measures isolated from the dynamics of work, distanced from the reality of workers, producing inadequate work conditions ${ }^{(17-18)}$ and adding a negative impact on the implementation of preventive measures for this event.

The lack of time and the shortage of staff and knowledge, associated with other priorities of care for hospitalized patients, hinder practices for prevention, leaving them in the background $^{(4,21,25,27)}$.

Health care involves knowledge and actions that relate to services and various professionals, thus making the health institution a high-risk environment for the occurrence of adverse events. Thus, nursing assumes a role of structural capital in organizations ${ }^{(28)}$, based on essential elements to ensure the quality of care ${ }^{(28-29)}$.

The occurrence of PI has a multifactorial origin, and the effort of all members of the multidisciplinary team is necessary to prevent it and treat it. However, the health management model still assumes the traditional paradigm of the hierarchical position centered on the physician ${ }^{(30)}$. In this study, it is stated that, for more than $50 \%$ of respondents, treatment is prescribed by this professional. In the same proportion, the nurse is the professional who evaluates the individual and the PI. These data evidence the breakdown of care.

Interdisciplinary collaborative practices can contribute to the reduction of adverse effects. Thus, in the context of PI care, there is a possibility of relative autonomy for the performance of specific nursing actions, but presents moments of complementarity with other professionals in which a relation of interdependence is maintained ${ }^{(30)}$, making the nursing professional an interlocutor between the members of the multidisciplinary team and the patient.

Regarding the questions directed to the treatment employed, the performance of procedures based on the biomedical model and carried out by different professionals, without a systematization of the process, perpetuates obsolete measures of a ritualistic practice, without reflection and harmful to the patient ${ }^{(4,21,26)}$. Thus, it is necessary to instrumentalize the professionals, with solutions based on the scientific discoveries of the institution's daily practice ${ }^{(25)}$, to program effective and early actions for prevention and treatment, with innovative proposals for an evidence-based care ${ }^{(4)}$, aiming to reduce and eradicate $\mathrm{PI}$.

\section{Study limitations}

Although this work is of unparalleled relevance, it has some limitations - among them, the reduced number of health institutions 
that serve this clientele and the restriction of the study population. As the cause of $\mathrm{PI}$ is multifactorial and its prevention and treatment is multiprofessional, the result does not reflect the integral care to the patient. Another difficulty was to find a theoretical model that emphasized the management of care.

\section{Contributions for the areas of nursing, health, or public policies}

$\mathrm{PI}$ is a theme of great value and extreme relevance for global and national nursing. Its prevention and care management are vast fields still to be explored, which directly impact on social and care-related issues concerning the patient, and are also important indicators of care quality and costs.

\section{CONCLUSIONS}

We observed in this study that there was no consensus among nursing professionals to identify factors that compose the care management for the prevention and treatment of PI. The adoption of isolated measures of care management and the understanding of the work dynamics diverge and are distanced from daily practices, thus evidencing the dichotomy in the policies of management of measures for the eradication of PI.

\section{REFERENCES}

1. European Pressure Ulcer Advisory Panel, National Pressure Ulcer Advisory Panel, Pan Pacific Pressure Injury Alliance. Prevention and treatment of pressure ulcers: quick reference guide [Internet]. Prague; 2014 [cited 2019 Apr 25]. Available from: https://www.npuap.org/wpcontent/uploads/2014/08/Updated-10-16-14-Quick-Reference-Guide-DIGITAL-NPUAP-EPUAP-PPPIA-16Oct2014.pdf

2. Moraes JT, Borges EL, Lisboa CR, Cordeiro DCO, Rosa EG, Rocha NA. Concept and rating of pressure injury: update of the National Pressure Ulcer Advisory Panel. Enferm Cent O Min [Internet]. 2016 [cited 2018 Jun 24];6(2):2292-306. Available from: http://www.seer.ufsj.edu.br/ index.php/recom/article/view/1423

3. Brandão E, Mandelbaum M, dos Santos I. A challenge in nursing care: preventing pressure ulcers in the client. Rev Pesqui Cuid Fundam[Internet]. 2013 [cited 2018 Jun 26];5(1):3221-8. Available from: http://www.seer.unirio.br/index.php/cuidadofundamental/article/view/1956

4. Alencar JR, Vasconcelos JMB, Caliri MHL, Beserra ICS. Prevention and treatment of pressure ulcers in the daily lives of intensivist nurses. Rev Rene [Internet]. 2013 [cited 2017 Sep 13];14(1):148-57. Available from: http://www.redalyc.org/articulo.oa?id=324027985017

5. Borghardt AT, Prado TN, Bicudo SDS, Castro DS, Bringuente MEO. Pressure ulcers in critically ill patients: incidence and associated factors. Rev Bras Enferm [Internet]. 2016 [cited 2017 Sept 13];69(3):431-8. Available from: http://dx.doi.org/10.1590/0034-7167.2016690307i

6. Dantas ALM, Ferreira PC, Valença CN, Diniz KD, Nunes JP, Germano RM. Complications of pressure ulcers in severely ill patients: a descriptiveexploratory study. O Braz J Nurs [Internet]. 2013 [cited 2013 Jul 14];12(2):319-29. Available from: http://www.objnursing.uff.br/index.php/ nursing/article/view/3794

7. Melleiro MM, Tronchin DR, Baptista CMC, Braga AT, Paulino A, Kurcgant P. Pressure ulcers prevalence indicators and patient falls incidence in teaching hospitals in the city of São Paulo. Rev Esc Enferm USP [Internet]. 2015 [cited 2019 Apr 25];49(Spe 2):55-9. Available from: http:// www.scielo.br/pdf/reeusp/v49nspe2/en_1980-220X-reeusp-49-spe2-0055.pdf

8. Galvão NS, Neto DL, Oliveira AP. Aspectos epidemiológicos e clínicos de pacientes com úlcera por pressão internados em uma instituição hospitalar. Estima [Internet]. 2015 [cited 2018 Jun 26];13(3). Available from: https://www.revistaestima.com.br/index.php/estima/article/view/106

9. Aued GK, Bernardino E, Peres AM, Lacerda MR, Dallaire C, Ribas EN. Clinical competences of nursing assistants: a strategy for people management. Rev Bras Enferm [Internet]. 2016 [cited 2017 Sep 13];69(1):130-7. Available from: http://dx.doi.org/10.1590/0034-7167.2016690119i

10. Vasconcelos JMB, Caliri MHL. Nursing actions before and after a protocol for preventing pressure injury in intensive care. Esc Anna Nery [Internet]. 2017 [cited 2017 Sep 13];21(1):e20170001. Available from: http://www.scielo.br/pdf/ean/v21n1/en_1414-8145-ean-21-01-e20170001.pdf

11. Pieper B, Mott M. Nurses' knowledge of pressure ulcer prevention, staging, and description. Adv Wound Care [Internet]. 1995 [cited 2012 Jun 3];8(3)34-40. Available from: https://www.ncbi.nlm.nih.gov/pubmed/7795877

12. Miyazaki MY, Caliri MHL, Santos CB. Knowledge on pressure ulcer prevention among nursing professionals. Rev Latino-Am Enfermagem [Internet]. 2010 [cited 2012 June 3];18(6). Available from: http://www.scielo.br/pdf/rlae/v18n6/22.pdf

13. Alexandre NMC, Coluci MZO. Content validity in the development and adaptation processes of measurement instruments. Ciênc Saúde Coletiva [Internet]. 2011 [cited 2019 Apr 25];16(7):3061-8. Available from: http://www.scielo.br/pdf/csc/v16n7/06.pdf

14. Barros ASX. Expansão da educação superior no Brasil: limites e possibilidades. Educ Soc [Internet]. 2015 [cited 2019 Apr 25];36(131):361-90. Available from: http://www.scielo.br/pdf/es/v36n131/1678-4626-es-36-131-00361.pdf

15. Caetano AS, Prado JTC. Labor market: general conditions of nursing work. Divulg Saúde Debate [Internet]. 2016 [cited 2019 Apr 27];56:98102. Available from: http://cebes.org.br/site/wp-content/uploads/2016/12/Divulga\%C3\%A7\%C3\%A30_56_Cofen.pdf\#page=100

16. Gunningberg L, Mårtensson G, Mamhidir AG, Florin J, Athlin MA, Bååth C. Pressure ulcer knowledge of registered nurses, assistant nurses and student nurses: a descriptive, comparative multicentre study in Sweden. Int Wound J [Internet]. 2013 [cited 2013 Set 30];12(4):463-8. Available from: https://onlinelibrary.wiley.com/doi/full/10.1111/iwj.12138

17. Silveira CD, Stipp MAC, Mattos VZ. Intervening factors in nursing work satisfaction in a Rio de Janeiro hospital. Rev Eletrônica Enferm [Internet]. 2014 [cited 2017 Sep 14];16(1):100-8. Available from: https://revistas.ufg.br/fen/article/view/21002 
18. Novarettil MCZ, Santos EV, Quitério LM, Daud-Gallottil. Nursing workload and occurrence of incidents and adverse events in ICU patients. Rev Bras Enferm [Internet]. 2014 [cited 2017 Sep 14];67(5):692-9. Available from: http://dx.doi.org/10.1590/0034-7167.2014670504

19. Peixoto LS, Gonçalves CL, Costa TD, Tavares CMM, Cavalcanti ACD, Antunes C. Permanent, continuous and of use Education: revealing its concepts. Enferm Glob [Internet]. 2013 [cited 2019 Apr 25];12(1):307-22. Available from: http://www.redalyc.org/articulo. oa?id=365834848017

20. Ministério da Saúde (BR). Portaria n 529, de $1^{\circ}$ de abril de 2013. Aprova o Programa Nacional de Segurança do Paciente (PNSP). Diário Oficial da União [Internet]. 2013 Apr 2 [cited 2014 Jan 24]. Available from: http://www.saude.mt.gov.br/upload/controle-infeccoes/pasta2/ portaria-msgm-n-529-de-01-04-2013.pdf

21. Cruz JDAC, Camargo AFS, Cruz NM, Moura LA, Lubarino DA, Brito RKM. Ulcer prevention of pressure and patient safety: nurses perceptions in intensive care. Rev Contexto Saúde [Internet]. 2015 [cited 2017 Sep 14];15(28):62-6. Available from: https://www.revistas.unijui.edu.br/ index.php/contextoesaude/article/view/3906

22. Silva DRA, Bezerra SMG, Costa JP, Luz MHBA, Lopes VCA, Nogueira LT. Pressure ulcer dressings in critical patients: a cost analysis. Rev EsC Enferm USP [Internet]. 2017 [cited 2018 Jan 24];51:e 03231. Available from: http://dx.doi.org/10.1590/s1980-220x2016014803231

23. Nogueira LS, Koike KM, Sardinha DS, Padilha KG, Sousa RM. Nursing workload in public and private intensive care units. Rev Bras Ter Intensiva [Internet]. 2013 [cited 2019 Apr 25];25(3):225-32. Available from: http://www.scielo.br/pdf/rbti/v25n3/en_0103-507x-rbti-25-03-0225.pdf

24. Lima AFC, Castilho V. Body mobilization for prevention of pressure ulcers: direct labor costs. Rev Bras Enferm [Internet]. 2015 [cited 2017 Nov 30];68(5):930-36. Available from: http://dx.doi.org/10.1590/0034-7167.2015680523i

25. Lima AFC, Castilho V, Baptista CMC, Rogenski NMB, Rogenski KE. Direct cost of dressings for pressure ulcers in hospitalized patients. Rev Bras Enferm [Internet]. 2016 [cited 2017 Nov 30];69(2):290-97. Available from: http://dx.doi.org/10.1590/0034-7167.2016690212i

26. Santos CT, Oliveira MC, Pereira AGS, Suzuki LM, Lucena AF. Pressure ulcer care quality indicator: analysis of medical records and incident report. Rev Gaúcha Enferm [Internet]. 2013 [cited 2018 June 27];34(1):111-8. Available from: http://dx.doi.org/10.1590/ S1983-14472013000100014

27. Qaddumi J, Khawaldeh A. Pressure ulcer prevention knowledge among Jordanian nurses: a cross-sectional study. BMC Nurs [Internet]. 2014 [cited 2014 Apr 20];13(1):6. Available from: http://bmcnurs.biomedcentral.com/articles/10.1186/1472-6955-13-6

28. Cordeiro ALAO, Fernandes JD, Mauricio MDLL, Silva RMO, Barros CSMA, Romano CMC. Structural capital in the nursing management in hospitals. Texto Contexto Enferm [Internet]. 2018 [cited 2018 June 23];27(2):e4880016. Available from: http://dx.doi. org/10.1590/0104-07072018004880016

29. Rossaneis MA, Gabriel CS, Haddad MCL, Melo MRA, Bernardes A. Quality indicators used in the nursing services of teaching hospitals. Rev Eletrônica Enferm [Internet]. 2014[cited 2018 Jun 24]:16(4):769-76. Available from: https://doi.org/10.5216/ree.v16i4.22956 